\title{
Acute Toxicity of Methanolic Extract of Anabasis articulata Stems
}

\author{
Fahem M. Mahmood ${ }^{1}$, Waleed K. Abdulsahib ${ }^{2}$ \\ ${ }^{1}$ Al-Nahrain University/ College of Medicine/ Pathology and Forensic Medicine Department \\ ${ }^{2}$ Al-Nahrain University/College of Medicine/Pharmacology Department
}

\begin{abstract}
Background: The LD50 value, defined as the statistically derivative dose that, when given in an acute toxicity test, is predictable to cause death in $50 \%$ of the treated animals in a specified period, is presently the basis for toxicological classification of chemicals. Anabasis articulata also called Ajrem, broadly distributed in the desert of Iraq and widely used for treatment of eczema, fever, kidney infections and diabetes. Objective: to investigate the acute toxicity of methanolic extract of Anabasis articulata stems. Subjects and methods: safety of methanolic extract that displayed potential antiangiogenic activity was tested against two species of animals: rats and mice. Swiss albino mice were used to evaluate the toxicity of the methanolic extract of Anabasis articulata. Animals were orally feed with serial doses of the extract between 2.5 to $30.0 \mathrm{~g} / \mathrm{kg}$ body weight and detected continuously for the first $4 \mathrm{~h}$ and then every hourfor the next $24 \mathrm{~h}$, then 6 hourly for $48 \mathrm{~h}$ (72 h, acute toxicity), after two weeks the results were collected. In addition to above rats were also fed with $5000 \mathrm{mg} / \mathrm{kg}$ of extract. Subsequent oral administration of Anabasis articulata methanolic extract the toxicity in the animals was done by evaluating the effects of herb on body weight, biochemical parameters, and histopathological investigation ofintestine, liver, lung, spleen, heart, stomach, testisand kidney. Results: The average acute toxicity value (LD50) of Anabasis articulata stemsmethanolic extract was found to be $26.18 \mathrm{~g} / \mathrm{kg}$ body weight. The extract reduced glucose level significantly, the remaining biochemical findingsdisplay no significant different in comparison to control. Body weight was detected in totally of the groups that treated with the extract. No significant changes in the body weight happen throughout the study, and no important alteration in histopathological study. Conclusion: The LD50 value indicated the drug to be fairly safe in single dose treatment. The study also presented the extract had worthyhypoglycemiceffects.
\end{abstract}

Keywords: Acute toxicity, Anti angiogenic herb, lethal dose 50\%, Anabasis articulata, stems

\section{Introduction}

Anabasis articulata $(A A)$, also called Ajremor Berry bearing glasswort, is widely distributed in Iraqi, Syrian, Egyptian and Algeriandesert. Anabasis articulata is mostly used in folk medicine to treat diabetes, fever, eczema and kidney infections. Anabasis articulatais a one species of the genus Anabasis. It is a salt-tolerant xerophyte of the Chenopodiaceaefamily. Anabasis articulata is Dwarf shrub (chamaephyte), 30-60 cm. Stems are woody to half their length or more, tortuous or erect. Branches are opposite with more or less equal brittle, internodes, the older ones with split and peeling bark. Lethal dose that kill fifty percent of animals $\left(\mathrm{LD}_{50}\right)$ is a typical measurement of acute toxicity that is recorded in milligrams $(\mathrm{mg})$ of herbal extract per kilogram $(\mathrm{kg})$ of body weight of assessment animal. $\mathrm{LD}_{50}$ denotes the individual dose needed to kill fifty percent of a population of assessment animals (e.g., fish, rats, mice, cockroaches). As $\mathrm{LD}_{50}$ values are standard measurements, it is conceivable to compare relative toxicities among the same species. The lesser the $\mathrm{LD}_{50}$ dose, the more toxic (1). Anabasis articulata evaluated previously in chorioallantoic assay of having important antiangiogenic effect, so, this study was constructed to investigate the acute toxicity of anabasis articulata to be formulated later for using for treatment of rheumatoid arthritis(2).

\section{Materials and Methods}

The lethal dose killing fifty percent of animals $\left(L D_{50}\right)$ Lethal Dosethat kill $50 \%$ of animals utilized to detect the dose that should be tested in vivo study and to clinical trial later on; as the beginning concentration is $(10 \%)$ of the $\mathrm{LD}_{50}$
(3). The $\mathrm{LD}_{50}$ study was done using ninety sixmale and female Swiss albino mice weighing $175-250 \mathrm{~g}$ each. The animals were in the same way distributed into fourteen treatment groups: 7 male groups, 7 female groups and double control groups (one male and one female group), where six animals in each group. Wholly animals provided with water and foodand were permitted to adapt to the research laboratory circumstances for seven days previous the starting of the experiment. After deprivation of food overnight, the animals in control group take water vehicle of $2 \%$ Tween 80 solution orally, and each treated group take orally the methanol extract ofAnabasis articulata, which was prepared via diffusing $8.0 \mathrm{~g}$ in $10 \mathrm{ml}$ volume of $2 \%$ Tween 80 in the following doses: 2.5, 5.0,10.0, 15.0, 20, 25, and $30.0 \mathrm{~g} / \mathrm{kg}$ (4),(5). The animals were detected for death or change in general behavior and other physiological activities. Observation of animal continued for the first 4 hours and then every $24 \mathrm{~h}$ for the following $48 \mathrm{~h}$ after giving of the extract (6), (7)

\section{Acute Toxicity Study}

The acute oral toxicity was assessed following the World Health Organization (WHO) guideline (WHO, 2000) and the Organization of Economic Co-operation and Development (OECD) guideline for chemical testing (5) . Twenty four rats were chosen by stratified randomization and then distributed into four groups of six each. The first two group served as treatment (six males and six females) and the other two control groups served as control (six males and six females), The treated groups were orally given the methanol extract of Anabasis articulata (diluted in DW ) in a single dose of 5.0 $\mathrm{g} / \mathrm{kg}$ body weight, while the control groups administered only water vehicle. The day one of the dosing was taken as Day 0 whereas the day of sacrifice was labeled as Day 14 (8). The

Volume 6 Issue 1, January 2017 


\section{International Journal of Science and Research (IJSR) \\ ISSN (Online): 2319-7064}

Index Copernicus Value (2015): 78.96 | Impact Factor (2015): 6.391

following parameters were calculated:Mortality, Body weight, Relative organ weight, Serum biochemistry and Microscopic examination(5),(9). Mortality: During the fourteen days period, all the animals were detected daily for clinical signs and mortality patterns. Body weight: The body weight of each rat was calculated using a sensitive balance during study period, once on day 0 , day 7 and day 14 of experiment.Relative Organ Weight: On day 14 of the study period, all the animals were euthanized byexsanguination under anesthesia of chloroform. Diverse organs namely the brain, heart, liver, kidneys, stomach, spleen, and sex organs werecautiously dissected out and weighed in grams (absolute organweight). The relative organ weight of each animal was thencalculated as follows:

Relative organ weight $=$ (absolute organ weight $(G) /$ body weight of rat on sacrifice day $(G)) * 100$

Preparation of sera samples and Serum biochemistry: On Day 14 of the experiment period, all the animals under anesthesia of chloroform, blood samples were drawn from the heart puncture of each animal. The samples were collected in sterile empty test tubes (without anticoagulant) and allowable in standing place for about 30 minute after that you find the blood clotted(10). Then these samples were centrifuged at $3000 \mathrm{rpm}$ for about $10 \mathrm{~min}$ and quickly clear serum samples were aspirated off and flash freeze it in -80 ${ }^{0} \mathrm{C}$ to preserve our complement for next assay.

The following biochemical parameters were determined calorimetrically by using the standard ready-to-use kits and methods of Human; blood glucose, blood urea, serum creatinine, glutamate oxaloacetate transaminase (GOT, AST), glutamate pyruvate transaminase (GPT, ALT), total bilirubin, conjugated bilirubin, the manufacturer instructions for each biochemical parameter were followed for the above investigations(11).

\section{Histopathological examination}

Examination of the organs carried out microscopically. Tissue samples from the heart, brain, liver, kidneys, and spleen, stomach and sex organs handled carefully and were putted in container contain 50-60 ml of 10\% neutral buffered formalin to preserve tissue from degradation, and to keep the structure of the cell and of sub-cellular components such as cell organelles (e.g., nucleus, endoplasmic reticulum, mitochondria)(12). These were processed manually. After dehydration and embedding, sections were cut at 4-5 $\mu$ with the rotary microtone, stained with hematoxylin and eosin and examined microscopically.

\section{Results}

The Lethal Dose kills fifty percent of animals $\left(\mathrm{LD}_{50}\right)$ After administration of a single dose of the serial concentrations of methanol extract of Anabasis articulata to each of the treated groups of mice (males and females) and the control group is given the vehicle, according to these, results were recorded and represented in the following table (1):
Table 1: The numbers and percentages of death between mice in the different groups and different administered doses

\begin{tabular}{|c|c|c|c|c|}
\hline $\begin{array}{l}\text { Dose } \\
(\mathrm{g} / \mathrm{kg})\end{array}$ & \begin{tabular}{|c|} 
No. of mice \\
(Male \& \\
Female)
\end{tabular} & $\begin{array}{c}\text { No. of } \\
\text { Dead mice }\end{array}$ & $\begin{array}{l}\text { Accumulative } \\
\text { Percentage (\%) }\end{array}$ & $\begin{array}{c}\text { Mean } \\
\text { accumulative } \\
\text { percentage }(\%\end{array}$ \\
\hline \multirow{2}{*}{$\begin{array}{c}\text { Control } \\
(0)\end{array}$} & 6 Male & 0 & 0 & \multirow[t]{2}{*}{0} \\
\hline & 6 Female & 0 & 0 & \\
\hline \multirow[t]{2}{*}{2.5} & 6 Male & 0 & 0 & \multirow[t]{2}{*}{0} \\
\hline & 6 Female & 0 & 0 & \\
\hline \multirow[t]{2}{*}{5} & 6 Male & 0 & 0 & \multirow[t]{2}{*}{0} \\
\hline & 6 Female & 0 & 0 & \\
\hline \multirow[t]{2}{*}{10} & 6 Male & 1 & 16.7 & \multirow[t]{2}{*}{8.35} \\
\hline & 6 Female & 0 & 0 & \\
\hline \multirow[t]{2}{*}{15} & 6 Male & 1 & 16.7 & \multirow[t]{2}{*}{16.7} \\
\hline & 6 Female & 1 & 16.7 & \\
\hline \multirow[t]{2}{*}{20} & 6 Male & 1 & 16.7 & \multirow[t]{2}{*}{25} \\
\hline & 6 Female & 2 & 33.3 & \\
\hline \multirow[t]{2}{*}{25} & 6 Male & 2 & 33.3 & \multirow[t]{2}{*}{41.65} \\
\hline & 6 Female & 3 & 50 & \\
\hline \multirow[t]{2}{*}{30} & 6 Male & 3 & 50 & \multirow[t]{2}{*}{58.35} \\
\hline & 6 Female & 4 & 66.7 & \\
\hline
\end{tabular}

The Lethal dose which killed fifty percent of mice (both sexes) receiving the serial concentrations of methanol extract is represented in figure (1).

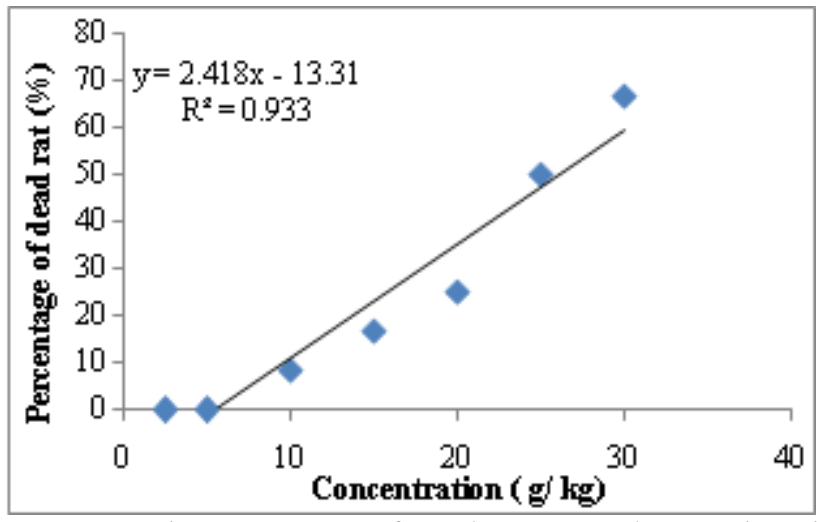

Figure 1: The $\mathrm{LD}_{50}$ curve of Anabasis articulata methanol extract on male and female mouse groups.

$\mathrm{LD}_{50}$ value of Anabasis articulata methanol extract was calculated from the linear regression equation $(y=2.418 \mathrm{x}-$ 13.312), which $\mathrm{LD}_{50}$ equals to $26.18 \mathrm{~g} / \mathrm{kg}$. Where: $\mathrm{y}=$ the percentage of dead rats andx= concentration.

\section{Acute toxicity study of Anabasis articulata methanol} extract in rats

After the rats were orally given a single dose of $5 \mathrm{~g} / \mathrm{kg}$ of the methanol extract of Anabasis articulata to the tested animals, neither signs of toxicity nor death of rats were observed during 14 days of the acute toxicity experiment period.The alterations of body weight at day zero, day seven and day fourteen were recorded and also the relative organ weights were calculated at day 14, organ tissue samples and blood samples were also collected at day14 from treated groups and their controls.

The weight of the animalsin the acute toxicity study Results show the changes in weight between the treatment groups (both sexes) in compared to their control groups during the fourteen days of the study. Weights of both groups were measured three times during the study, at day zero, 


\section{International Journal of Science and Research (IJSR) \\ ISSN (Online): 2319-7064 \\ Index Copernicus Value (2015): 78.96 | Impact Factor (2015): 6.391}

seven and fourteen, (Figure $2 \& 3$ ). There was no significant changes in weight among treatment groups in comparison to their controls $(\mathrm{P}>0.05)$ for both male and female groups. At day zero $P$ value $=(0.059)$ and $(P=0.063)$ for male and female rats and their control respectively. At day seven $P$ value $=(0.567)$ and $(0.086)$ for male and female rats and their control respectively. While at day fourteen $P$ value $=$ $(0.7)$ and (0.066) for the male and female rats respectively, in compared with their controls, (Table 2).

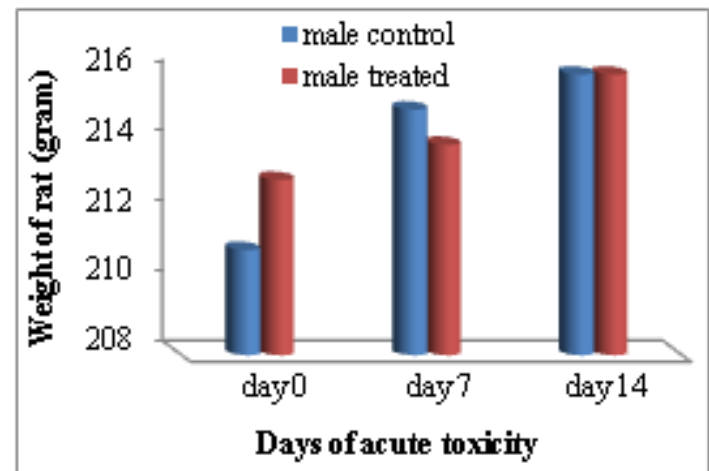

Figure 2: Weight changes in the treated male rats and their controls at days zero, seven and fourteen.

* Data are expressed as Mean $\pm \mathrm{SD}, \mathrm{n}=10$ for each group.

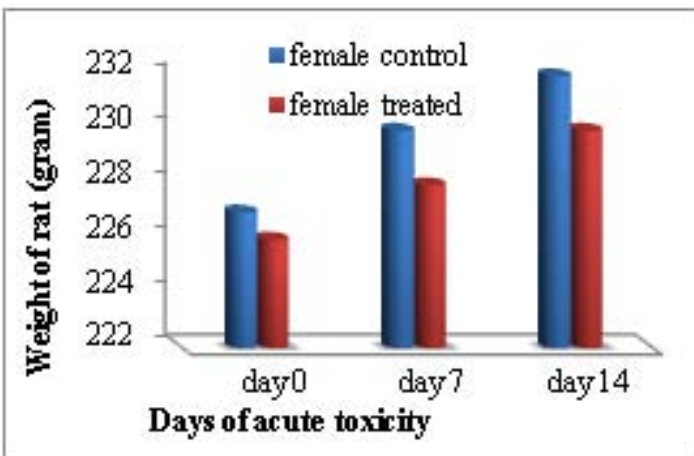

Figure 3: Weight changes in the treated female rats and their controls at days zero, seven and fourteen

* Data are expressed as Mean $\pm \mathrm{SD}, \mathrm{n}=10$ for each group.
Table 2: The weight of the animals (males and females) during the days of experiment

\begin{tabular}{|c|c|c|c|c|}
\hline Time / Day & \multicolumn{4}{|c|}{ Weight $(g)^{*}$} \\
\cline { 2 - 5 } & $\begin{array}{c}\text { Male control } \\
\text { group }\end{array}$ & $\begin{array}{c}\text { Male treated } \\
\text { group }\end{array}$ & $\begin{array}{c}\text { Female } \\
\text { control } \\
\text { group }\end{array}$ & $\begin{array}{c}\text { Female } \\
\text { treated } \\
\text { group }\end{array}$ \\
\hline Day Zero & $213 \pm 3.7$ & $212.8 \pm 3.7$ & $227.3 \pm 4.5$ & $226.9 \pm 4.5$ \\
\hline Day 7 & $215.6 \pm 3.8$ & $214.8 \pm 3.31$ & $230.3 \pm 4.4$ & $228.9 \pm 4.47$ \\
\hline Day 14 & $216.3 \pm 3.3$ & $216.9 \pm 3.81$ & $232.3 \pm 4.46$ & $230.3 \pm 4.53$ \\
\hline
\end{tabular}

* Data are expressed as Mean $\pm \mathrm{SE}, \mathrm{n}=10$ for each group.

Relative organ weights in the acute toxicity study

Results showed the changes in the relative weight of organs for treated male and female rats in compared to their controls, the results showed no significant changes occurred between treated groups and their control $(P>0.05)$, (Table 3.).

Table 3: Relative organ weights of rats receiving methanol extract of $A A$ stems and their controls after 14 days of acute toxicity experiment

\begin{tabular}{|c|c|c|c|c|}
\hline \multirow{2}{*}{\multicolumn{2}{|c|}{ Organs }} & \multicolumn{3}{|c|}{ Treatment* } \\
\hline & & $\begin{array}{c}\text { Anabasis } \\
\text { articulata } \\
5 \mathrm{~g} / \mathrm{kg}\end{array}$ & Control & P Value \\
\hline \multicolumn{5}{|l|}{ Male } \\
\hline & Heart & $0.591 \pm 0.02$ & $0.581 \pm 0.032$ & 0.61 \\
\hline & Brain & $0.370 \pm 0.01$ & $0.351 \pm 0.021$ & 0.28 \\
\hline & Liver & $6.031 \pm 0.26$ & $5.952 \pm 0.181$ & 0.10 \\
\hline & Kidneys & $1.652 \pm 0.09$ & $1.631 \pm 0.110$ & 0.68 \\
\hline & Spleen & $0.593 \pm 0.03$ & $0.611 \pm 0.031$ & 0.29 \\
\hline & Stomach & $3.381 \pm 0.20$ & $3.341 \pm 0.221$ & 0.79 \\
\hline & \begin{tabular}{|l|} 
Testes \\
\end{tabular} & $1.752 \pm 0.10$ & $1.801 \pm 0.075$ & 0.052 \\
\hline & Intestine & $5.712 \pm 0.211$ & $5.661 \pm 0.161$ & 0.53 \\
\hline \multicolumn{5}{|c|}{\begin{tabular}{|l|l|} 
Female & \multicolumn{1}{l}{ | } \\
\end{tabular}} \\
\hline & Heart & $0.618 \pm 0.041$ & $0.583 \pm 0.032$ & 0.28 \\
\hline & Brain & $0.372 \pm 0.012$ & $0.351 \pm 0.022$ & 0.742 \\
\hline & Liver & $6.031 \pm 0.211$ & $5.931 \pm 0.157$ & 0.454 \\
\hline & Kidneys & $1.681 \pm 0.111$ & $1.65 \pm 0.102$ & 0.73 \\
\hline & Spleen & $0.596 \pm 0.033$ & $0.601 \pm 0.031$ & 0.56 \\
\hline & Stomach & $3.412 \pm 0.245$ & $3.393 \pm 0.154$ & 0.40 \\
\hline & Ovaries & $0.373 \pm 0.044$ & $0.412 \pm 0.075$ & 0.36 \\
\hline & Intestine & $5.713 \pm 0.223$ & $5.743 \pm 0.152$ & 0.15 \\
\hline
\end{tabular}

Serum biochemical tests of rats in the acute toxicity study The rats received $(5 \mathrm{~g} / \mathrm{kg})$ of Anabasis articulata methanol extract, after 14 days, serum biochemical tests that done for both the tested animals and their controls. There was no significant difference between treated groups compared to their control groups $(P>0.05)$, except blood glucose level significantly reduced $(P=0.015) \&((P=0.001)$ in male \& female respectively when compared with the control, as illustrated in (Table 4). 


\title{
International Journal of Science and Research (IJSR) ISSN (Online): 2319-7064 \\ Index Copernicus Value (2015): 78.96 | Impact Factor (2015): 6.391
}

Table 4: The Serum biochemical tests for rats receiving single dose $(5 \mathrm{~g} / \mathrm{kg}$ of Anabasis articulata methanol extract and their controls

\begin{tabular}{|c|c|c|c|c|c|c|}
\hline \multirow{2}{*}{ Biochemical Tests } & \multicolumn{7}{|c|}{ Laboratory animals (Rat)* } \\
\cline { 2 - 8 } & \multicolumn{3}{|c|}{ Male } & \multicolumn{4}{c|}{ Female } \\
\cline { 2 - 8 } & Treatment group & Control group & P value & Treatment group & Control group & P value \\
\hline Blood glucose (mg/dl) & $75.8 \pm 1.4$ & $92.16 \pm 1.31$ & 0.015 & $92.1 \pm 1.2$ & $106.5 \pm 0.88$ & 0.001 \\
\hline Blood Urea (mg/dl) & $18.21 .1 \pm 0.41$ & $19.23 .1 \pm 0.6$ & 0.21 & $16.2 .6 \pm 0.61$ & $17.3 \pm 0.66$ & 0.100 \\
\hline S.Creatinine (mg/dl) & $0.456 \pm 0.017$ & $0.441 \pm 0.016$ & 0.665 & $0.486 \pm 0.027$ & $0.466 \pm 0.026$ & 1.0 \\
\hline TG (mg/dl) & $65.1 \pm 1.33$ & $66.8 \pm 1.66$ & 0.41 & $75.1 \pm 1.45$ & $73.3 \pm 1.55$ & 0.74 \\
\hline Cholesterol (mg/dl) & $104.6 \pm 1.3$ & $106 \pm 1.6$ & 0.32 & $112.3 \pm 0.76$ & $114.5 \pm 0.66$ & 0.61 \\
\hline HDL (mg/dl) & $6.6 \pm 0.14$ & $6.5 \pm 0.15$ & 0.755 & $7.5 \pm 1.11$ & $7.3 \pm 1.33$ & 0.764 \\
\hline Total protein (g/dl) & $6.8 \pm 0.07$ & $6.7 \pm 0.16$ & 0.17 & $6.4 \pm 0.09$ & $6.2 \pm 0.08$ & 1.0 \\
\hline Albumin (g/dl) & $3.2 \pm 0.0031$ & $3.1 \pm 0.003$ & 0.51 & $3.5 \pm 0.11$ & $3.4 \pm 0.07$ & 0.24 \\
\hline Calcium (mg/dl) & $9.8 \pm 0.31$ & $9.1 \pm 0.33$ & 1.0 & $9.1 \pm 0.41$ & $8.8 \pm 0.31$ & 0.32 \\
\hline Potassium (meq/l) & $6.3 \pm 0.25$ & $6 \pm 0.21$ & 0.628 & $5.8 \pm 0.08$ & $5.7 \pm 0.07$ & 0.71 \\
\hline ALT (SGPT) U/L & $24.1 \pm 0.60$ & $22.8 \pm 0.47$ & 0.448 & $28.8 \pm 0.60$ & $27.8 \pm 0.30$ & 0.11 \\
\hline AST (SGOT) U/L & $67.1 \pm 0.98$ & $64.8 \pm 0.65$ & 0.367 & $69.3 \pm 0.61$ & $71.8 \pm 0.49$ & 0.65 \\
\hline TotalBilirubin (mg/dl) & $0.28 \pm 0.022$ & $0.29 \pm 0.0221$ & 1.0 & $0.37 \pm 0.051$ & $0.39 \pm 0.053$ & 0.80 \\
\hline & $*$ * Data are expressed as Mean \pm SE, $\mathrm{n}=5$ for each group. & \\
\hline
\end{tabular}

\begin{abstract}
Histopathological examination for selected organs in the acute toxicity study

The histopathological study of the selected organs in the acute toxicity study in rats show no remarkable change when comparing treated and control groups.Figure (4) (B) displays normal glial cell and neural cells of the section taken from brain tissue treated rat group (received single dose of $5000 \mathrm{mg} / \mathrm{kg}$ methanol extract of Anabasis articulata diluted in DW orally by gastric gavage). Figure (5) (B) shows normal myocardial cells when taken a section of heart tissue of rat treated group. Figure (6) (B) illustrated normal goblet cells and villi after taken a section of intestinal tissue of treated group of the rat. Also figure (7) (B) demonstrated normal glomerulus, bowman's space, proximal collecting tubules and distal collecting tubules when taken a section of
\end{abstract}

liver tissue of treated group. Figure (8) (B) displays normal hepatic lobule composed of hepatocytes arranged in hepatic cords separated by sinusoids that drain into central vein liver tissue when take a section of liver tissue of treated group rat. Figure (9) (B) shows a section of spleen tissue of treated group with normal spleen tissue that is composed of white pulps and red pulps. Figure (10) (B) display normal gastric tissue when take a section from stomach tissue of treated animals. Figure (11) (B) shows normal seminiferous tubules lined with germ cells undergoing normal spermatogenesis taken from testicular tissue of treated group of rat. In addition to above, sections were taken from the brain, heart, intestine, kidney, liver, spleen, stomach and testes from control group as illustrated in the next figures.
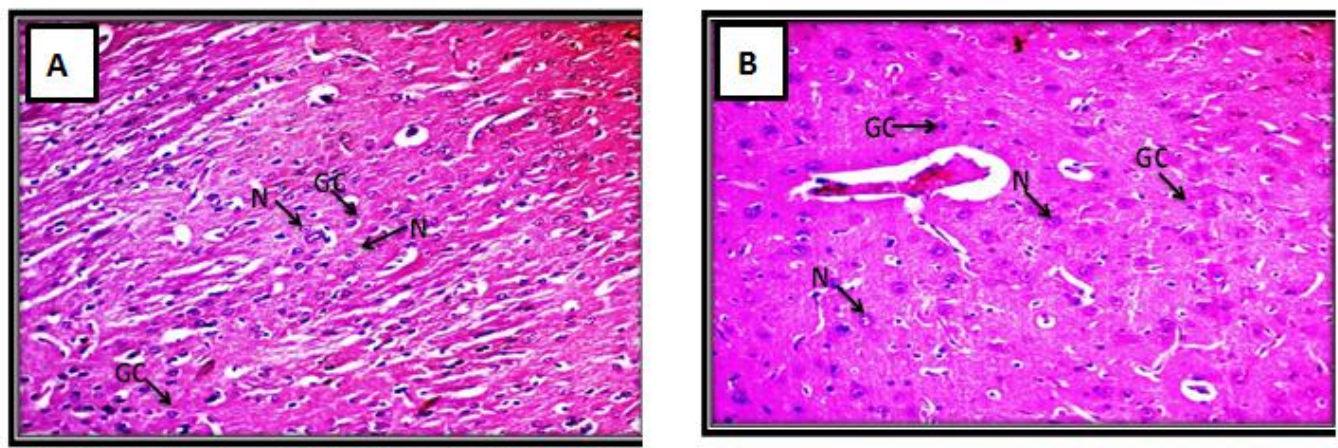

Figure 4: Section of rat brain tissue:(A) control group of rat (received DW orally) showing normal brain tissue, (B): treatment group (received single dose of $5000 \mathrm{mg} / \mathrm{kg}$ methanol extract of Anabasis articulata diluted in DW orally by gastric gavage) showing normal brain tissue H\& E stain (20X), GC: Glial Cells, N: Neural cell.
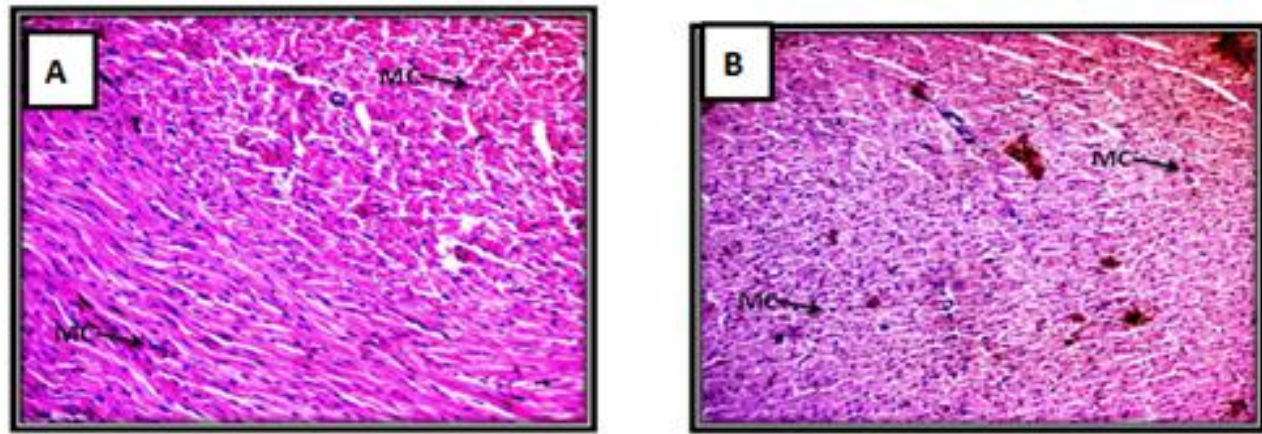

Figure 5: Section of heart tissue: (A) control group of rat (DW orally) showing normal myocardial cells, (B): treatment group received single dose of $5000 \mathrm{mg} / \mathrm{kg}$ methanol extract of Anabasis articulata diluted in DW orally by gastric gavage) showing normal myocardial cells, H\& E stain (20X), MC: Myocardial Cells.

\section{Volume 6 Issue 1, January 2017 www.ijsr.net}




\section{International Journal of Science and Research (IJSR) ISSN (Online): 2319-7064}

Index Copernicus Value (2015): 78.96 | Impact Factor (2015): 6.391
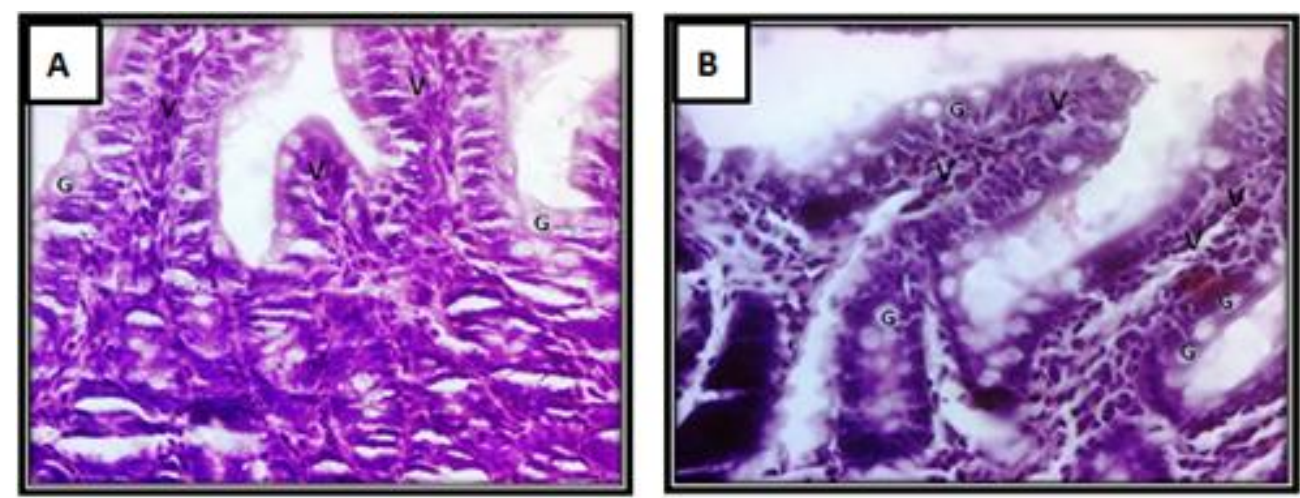

Figure 6: Section of intestinal tissue: (A) control group of rat (DW orally) showing normal goblet cells\& villi, (B): treatment group receiving (single dose of $5000 \mathrm{mg} / \mathrm{kg}$ methanol extract of Anabasis articulata diluted in DW orally by gastric gavage) showing normal goblet cells\& villi, H\& E stain (40X), G: goblet cells, V: villi.
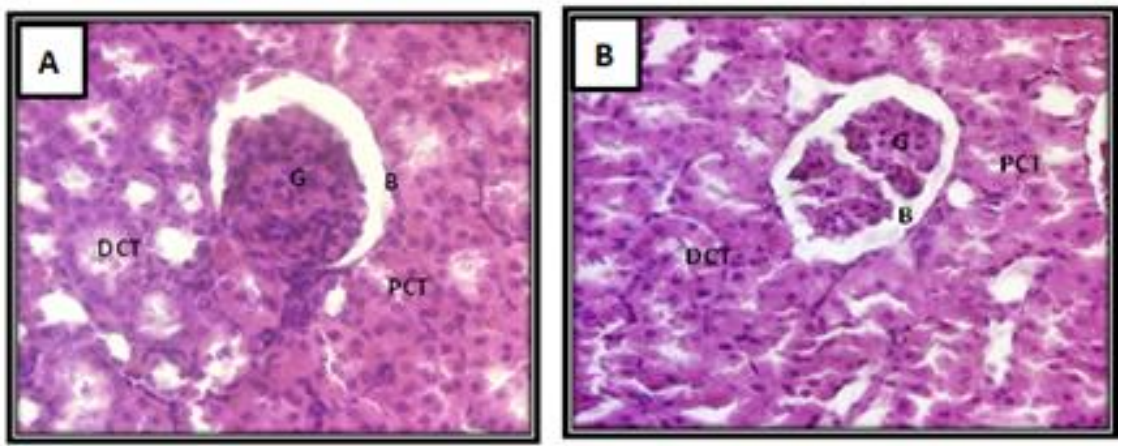

Figure 7: Section of kidney tissue:(A) control group rat (receive DW orally) showing normal glomerulus, bowman's space \& collecting tubules tissue,(B):treatment group received ( single dose of $5000 \mathrm{mg} / \mathrm{kg}$ methanol extract of $A$.A. diluted in DW orally by gastric gavage) showing normal glomerulus, bowman's space \& collecting tubules tissue, H\& E stain (40X), G: Glomerulus, B: Bowman's space, PCT: Proximal collecting tubules, DCT: Distal collecting tubules.
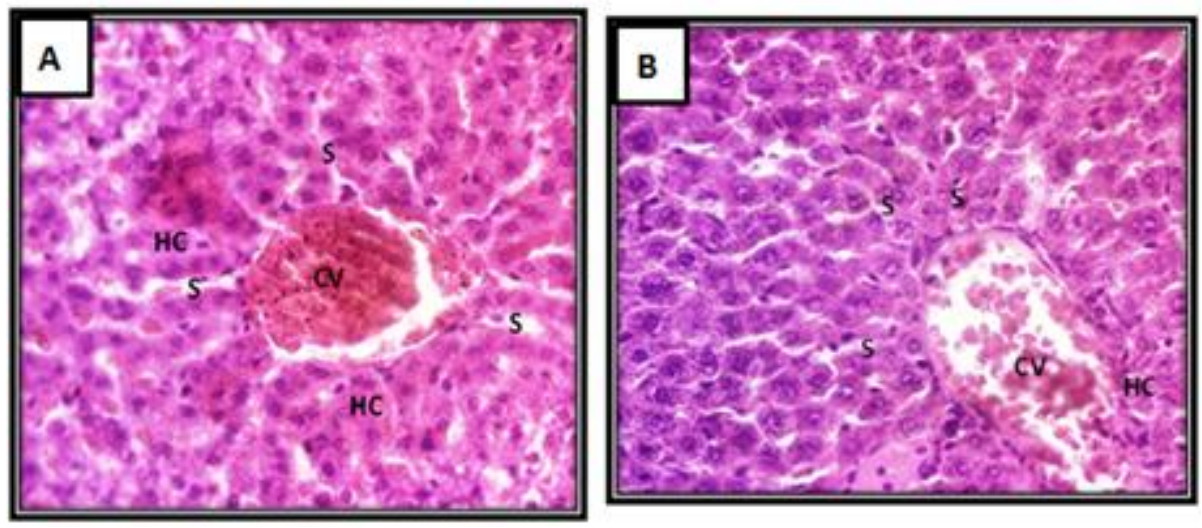

Figure 8: Section of liver tissue :(A) control group rat (receive DW orally) showing normal hepatic lobule composed of hepatocytes arranged in hepatic cords separated by sinusoids that drain into central vein ,(B): treatment group received (single dose of $5000 \mathrm{mg} / \mathrm{kg}$ methanol extract of $A . A$ ) showing normal hepatic lobule composed of hepatocytes arranged in hepatic cords separated by sinusoids that drain into central vein liver tissue, H\& E stain (20X), HC: Hepatic Cord, CV: Central Vein, S: Sinusoids.
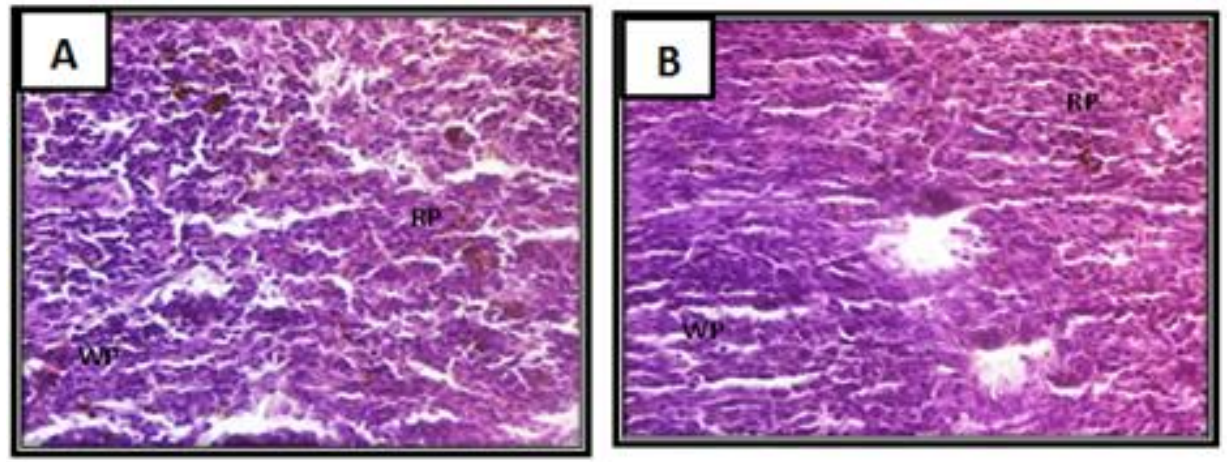

Figure 9: Section of spleen tissue: (A) control group rat (received DW orally) showing normal spleen tissue that composed from white pulps \& red pulps, (B) treatment group (received single dose of $5000 \mathrm{mg} / \mathrm{kg}$ methanol extract of $A . A$ diluted in DW

Volume 6 Issue 1, January 2017 www.ijsr.net 


\section{International Journal of Science and Research (IJSR) ISSN (Online): 2319-7064}

Index Copernicus Value (2015): 78.96 | Impact Factor (2015): 6.391

orally by gastric gavage) showing normal spleen tissue that composed from white pulps \& red pulps, H\& E stain (20X), WP: white pulp, RP: red pulp.
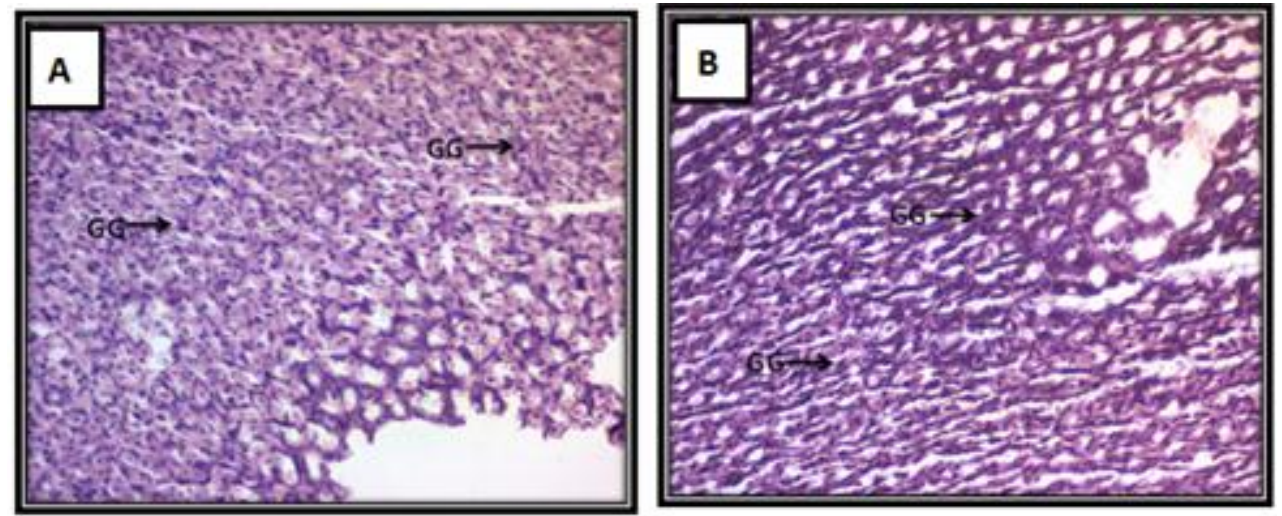

Figure 10: Section of stomach tissue: (A)control group rat (receive DW orally) showing normal gastric mucosa composed of mucous glands tissue,(B): treatment group (received single dose of $5000 \mathrm{mg} / \mathrm{kg}$ methanol extract of $A$.A diluted in DW orally by gastric gavage) showing normal gastric tissue, H\& E stain (20X), GG: Gastric Gland.
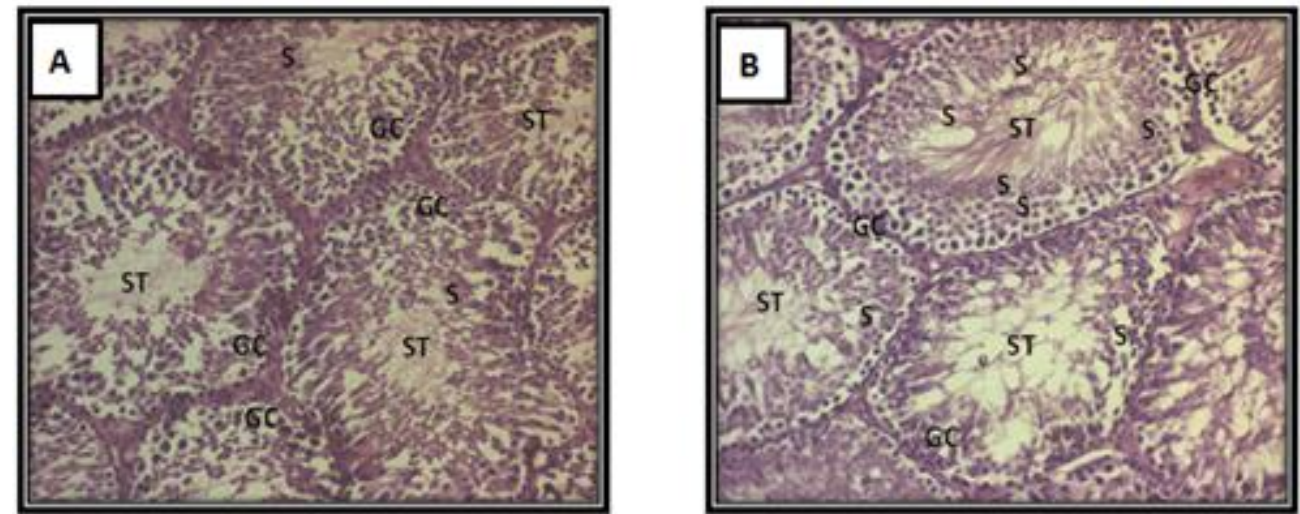

Figure 11: Section of testicular tissue:(A) control group of rat (receive DW orally) showing seminiferous tubules lined with germ cells undergoing normal spermatogenesis, (B): treatment group(received single dose of $5000 \mathrm{mg} / \mathrm{kg}$ methanol extract of $A$.A diluted in DW orally by gastric gavage) showing seminiferous tubules lined with germ cells undergoing normal spermatogenesis normal spermatogenesis, H\& E stain (20X), ST: Seminiferous Tubules, GC: germ cells, S: sperms.

\section{Discussion}

Lethal dose eradicate $50 \%$ of animals (LD50) is a typical measurement of acute toxicity that is quantified in milligrams $(\mathrm{mg})$ of the herb extract per kilogram $(\mathrm{kg})$ of body weight of animal that tested. LD50 describes the individual dose necessitated to kill fifty percent of inhabitants of test animals (e.g., rats, fish, mice, cockroaches). It is likely to compare relative toxicities among similar species because LD50 values are standard measurements. The lower LD50 value, mean the herb is a greater toxic (13).LD50 useful to detect the dose that should be experienced in vivo study and to clinical trial afterward; as the initial concentration is 10\% of the LD50 (Francesco et al., 2009). Acute toxicity study not only recognizes the lethal dose but additionally detect the modifications that happened on animals that take the herb. The animal used in acute toxicity study is rats while in LD50 documentation the animal used was mice this is to attain two animal species at least should be experienced in recognizing the acute toxicity (14). After the rats were orally given a single dose of the methanol extract $(5,000 \mathrm{mg} / \mathrm{kg})$ from the dried stems extract of Anabasis articulata neither signs of toxicity nor death of rats were detected during 14 days of trial period the acute toxicity. The results displayed that the methanol extract has
LD50 (26.18 g/kg). Kambouche and coworkers (2011)revealed that Algerian anabasis articulata leaves is more toxic than Iraqi anabasis articulata stems, these findings give a reason of using plant stems in future clinical studies as stems is the safest aerial part. However, the dissimilarities between the two studies may be because of the difference in the plant part that used, the nature of landlivings where the plant has planted and the solvents used in extraction process as in Kamboucheet al (2011) used water in his study in the extraction process while in the present study methanol was used as a solvent in the extraction process. Neither internal organ weight nor body weight of treated rats groups was considerably changed when compare to the control group. The changes in body weight and organs weights from the control would reveal the toxicity of the ingredient(16). The clinical biochemistry analyses were done to estimate the potential changes in hepatic and renal functions affected by the extracts. Liver and kidney function analysis is essential in the toxicity assessment of drugs and plant extracts as they are both essential for the survival of an organism(17).The methanol extract of Anabasis articulata extract presented no sign of toxicity at $5 \mathrm{~g} / \mathrm{kg}$ in the rats. Blood profile results showed no major changes in comparisons to the control groups for both male and female rats, except there is obvious reduction in the blood glucose

\section{Volume 6 Issue 1, January 2017




\section{International Journal of Science and Research (IJSR) \\ ISSN (Online): 2319-7064}

Index Copernicus Value (2015): 78.96 | Impact Factor (2015): 6.391

levels of treated group. Usually, injury to the parenchymal liver cells marks an elevation of both transaminases in the blood (18). Therefore, the non-important change in ALT, AST activities intensely propose that the administration of Anabasis articulata methanol extract did not change the hepatocytes as also observed in the histopathology of liver tissue. Similarly, there was no important alteration in urea and creatinine in the Anabasis articulata methanol extract treatment group when compared to the control group. Any augmentation in urea and creatinine levels is solitary detected if there is clear impairment to functional nephrons (19). This outcome was further established by histopathological clarifications of the kidney tissue. Therefore, the consequences presented in this study supports that the methanolic extract of Anabasis articulata did not modify the liver or renal functions and further support the non-toxic nature of theextract. Above findings compatible with Kambouche et al (2011) that proved the safety of Anabasis articulata in rats, furthermore, Azaa et al(2014) demonstrated the hepatoprotective effect of Anabasis articulata in dimethylnitosamine-induced liver injury and fibrosis in rats.

Anabasis articulata in our study proved to have antidiabetic effect and this finding are in agreement with Kamboucheet al (2011) that also proved that aqueous extract of Anabasis articulata leaves diminished the hyperglycemia level and improved glucose tolerance in alloxan diabetic mice. Furthermore,Nadia co-workers (2012) revealed Anabasis articulata has several positive actions in governing diabetes and consequence problems induced in pancreas and liver and may applicant as natural antidiabetic drug. In the elegant of previous findings, the antidiabetic action of the current extract could be attributed to saponin constituents, and its antihyperglycemic action is through the discharge of insulin from the pancreas that is, it utilizes a direct insulin-tropic influence, or it could be owing to the insulin like effect of the active principle (saponin) present in the extract. In addition to above, Anabasis articulata rich in flavonoids that have proposed as effective supplements for management and prevention of diabetes and its long-term complications based on in vitro and animal models(22). Besides their antioxidative activity, numerous flavonoids were revealed to act on biological targets involved in type 2 diabetes mellitus such as: $\alpha$-glycosidase, glucose co-transporter or aldose reductase.(23). Also flavonoids stimulate insulin production from the existing $\beta$-cells of pancreas (24) and improve lipid metabolizing enzymes. In addition, it has been reported a flavonoid increased glucose uptake and increased GLUT4 translocation (25). In addition, it has been found that many types of flavonoids were served as a potential agent for glycemic control through enhancement of insulin-dependent receptor kinase activity, thereby inducing the insulin signaling pathway causing increased glucose transporter-4 (GLUT-4) translocation increased glucose uptake. In skeletal muscle, flavonoid significantly increases intracellular calcium concentration which may induce (GLUT-4) translocation with consequent glucose uptake(26).Moreover, histopathological examinations reveal the safety of orally administered Anabasis articulata, whereno histological changes detected in the organs of treated groups. These data similar to the finding of Azaaet al (2014) that additionally proved that Anabasis articulataextract displayed in vivo hepatoprotective and therapeutic effects against DMN-induced liver damage and may act as a valuable agent in governing the development of hepatic fibrosis through decline of oxidative stress and recovering liver function.

\section{Conclusion}

The LD50 value showed the methanolic extract of Anabasis articulata stems fairly safe in single dose treatment. The study also presented that the stems extract had good hypoglycemic outcome.

\section{References}

[1] Amein A, Abdul Aziz A, Mohammad A, Nisar A. Oral and intra-peritoneal LD50 of thymoquinone, an active principle of NIGELLA SATIVA, in mice and rats. J Ayub Med Coll Abbottabad. 2008; 20(2).

[2] Abudalsahib W , Abd A, Jumaa B. Antiangiogenic Activity of Iraqi Anabasis articulata Stems In vivo Study. International Journal of Science and Research. 2016; 5 (9).

[3] George F, Zohar Z, Harinder P, Klaus B. The biological action of saponins in animal systems: a review". From pla. British Journal of Nutrition. 2002; 88(6): p. 587605.

[4] Lorke D. A new approach to practical acute toxicity testing. Arch.Toxicol. 1983; 54: p. 275 - 287.

[5] Stanley O, Florence C, David D, Gloria A, Sunday D, Kazeem SI, et al. Toxicity studies in rats fed nature cure bitters. African Journal of Biotenchology. 2005; 4(1): p. 72-78.

[6] Shah A, Garg S, Garg K. Subacute toxicity studies Pendimethalin in rats. Indian J. Pharm. 1997; 29: p. 322324.

[7] Bürger C, Fischer D, Cordenunzzi D, Batschauer D, Filho V, Soaresdos S. Acute and subacute toxicity of the hydroalcoholic extract from Wedelia paludosa Acmela brasilinsis (Asteraceae) in mice. J. Pharm. Sci. 2005; 8(2): p. 370-373.

[8] Kwan Y, Ibrahim D, Yeng C, Subramaniam S, Sreenivasan S. Acute and Subchronic Toxicity Study of Euphorbia hirta L. Methanol Extract in Rats. BioMed Research International. 2013; 182064: p. 14.

[9] Chunlaratthanaphorn S, LertprasertsukeN , Srisawat U, Thuppia A, Ngamjariyawat A, Suwanlikhid N, et al. Acute and subchronic toxicity study of the water extract from dried fruits of Piper nigrum L. in rats. J. Sci. Technol. 2007; 29(1): p. 109-124.

[10] Arzoumanian L. Technical Services News Bulletin.; 2003.

[11]Donovan J, Brown P. Blood collection. Curr Protoc Immunol. $2006 \mathrm{Jul} ; 1$.

[12] Weiss A, Delcour N, Meyer A, Klopfleisch R. Efficient and Cost-Effective Extraction of Genomic DNA from Formalin-Fixed and Paraffin-Embedded Tissues". Veterinary Pathology. $2011 \mathrm{Jul}$; 48(4): p. 834-8.

[13] Amein A, Abdul A, Mohammad A, Nisar A. Oral and intra-peritoneal LD50 of thymoquinone, an active principle of NIGELLA SATIVA, in mice and rats. J

\section{Volume 6 Issue 1, January 2017




\section{International Journal of Science and Research (IJSR) \\ ISSN (Online): 2319-7064 \\ Index Copernicus Value (2015): 78.96 | Impact Factor (2015): 6.391}

Ayub Med Coll Abbottabad. 2008 Amein Al-Ali; Abdul Aziz Alkhawajah ; 20(2).

[14] Katzung B. development and regulation of drugs. In basic and clinical pharmacology. 13th ed.: Mc graw hill lange; 2015. p. 71.

[15] Kambouche N, Merah B , Derdour A , Bellahouel S , Younos C, Soulimani R. Antihyperglycemic activity of $\beta$-sitoglucosid sterol isolated from the plant of Anabasis articulata (Forssk) Moq. Phytothérapie. 2011; 9: p. 2-6.

[16] Seewaboon S, Nirush L, Umarat S, Amornat T. Acute and subchronic toxicity study of the water extract from Tiliacora triandra (Colebr.) Diels in rats Songklanakarin. J. Sci. Technol. 2008; 30(6): p. 611619.

[17] Olorunnisola O, Bradley G, Afolayan A. Acute and subchronic toxicity studies of methanolic extract of Tulbaghia violacea rhizomes inWistar rats. African Journal of Biotechnology. 2012; 11: p. 14934-14940.

[18] Slichter S. Relationship between platelet count and bleeding risk in thrombocytopenic patients. Transfusion Medicine Reviews. 2004; 18(3): p. 153-167.

[19] Lameire N, Van Biesen W , Vanholder R. Acute renal failure. The Lancet. 2005; 365(9457): p. 417-430.

[20]Azza M, Mohga S, Maha Z, et al. Alleviation of Dimethylnitrosamine-Induced Liver Injury and Fibrosis by Supplementation of Anabasis articulata Extract in Rats. Indian J Clin Biochem. 2014; 29(4): p. 418-429.

[21] Nadia S, Azza M, Fatma S. Chemical constituents of the Egyptian Plant Anabasis articulata (Forssk) Moq and its antidiabetic effects on rats with streptozotocin-induced diabetic hepatopathy. Journal of Applied Pharmaceutical Science. 2012 Nadia S Metwally; Azza M Mohamed ; Fatma S ELSharabasy; 02(04): p. 54-65.

[22] Ramachandran V, Baojun X. Antidiabetic properties of dietary flavonoids: a cellular mechanism review. Nutrition \& Metabolism. 2015.

[23] Nicolle E , Faure P, Boumendjel A. Flavonoids as promising lead compounds in type 2 diabetes mellitus: molecules of interest and structure-activity relationship. Curr Med Chem. 2011; 18(17): p. 2661-72.

[24] Pari L, Srinivasan S. Antihyperglycemic effect of diosmin on hepatic key enzymes of carbohydrate metabolism in streptozotocin-nicotinamide-induced diabetic rats. Biomed Pharmacother. 2010; 64: p. 47781.

[25] Dhanya R, Arun K, Syama H, Nisha P , et al. Rutin and quercetin enhance glucose uptake in L6 myotubes under oxidative stress induced by tertiary butyl hydrogen peroxide. Food Chem. 2014; 158: p. 546-54.

[26] Sheweita S, Mashaly S, Newairy A, et al. Changes in Oxidative Stress and Antioxidant Enzyme Activities in Streptozotocin-Induced Diabetes Mellitus in Rats: Role of Alhagi maurorum Extracts. Oxid Med Cell Longev. 2016; 5264064. 